\title{
Effects of Processing (Boiling and Roasting) on the Nutritional and Antinutritional Properties of Bambara Groundnuts (Vigna subterranea [L.] Verdc.) from Southern Kaduna, Nigeria
}

\author{
Uche Samuel Ndidi, ${ }^{1}$ Charity Unekwuojo Ndidi, ${ }^{1}$ Idowu Asegame Aimola, ${ }^{1}$ \\ Obed Yakubu Bassa, ${ }^{1}$ Mary Mankilik, ${ }^{2}$ and Zainab Adamu ${ }^{1}$ \\ ${ }^{1}$ Department of Biochemistry, Ahmadu Bello University, Zaria 810001, Kaduna, Nigeria \\ ${ }^{2}$ Nigerian Institute of Leather and Science Technology (NILEST), Zaria 810001, Kaduna, Nigeria
}

Correspondence should be addressed to Uche Samuel Ndidi; usndidi@abu.edu.ng

Received 14 May 2014; Accepted 23 August 2014; Published 25 September 2014

Academic Editor: Raquel P. Guiné

Copyright (C) 2014 Uche Samuel Ndidi et al. This is an open access article distributed under the Creative Commons Attribution License, which permits unrestricted use, distribution, and reproduction in any medium, provided the original work is properly cited.

\begin{abstract}
This research analyzed the effect of processing (boiling and roasting) on the proximate, antinutrient, and mineral composition of Vigna subterranea seeds. The proximate composition analysis showed significant difference $(P<0.05)$ between the levels of crude lipid, crude fiber, gross energy, carbohydrate, and moisture content in the raw and processed V. subterranea. However, no significant difference $(P<0.05)$ was observed in protein content of processed $V$. subterranea as compared to the raw seeds. Analyses of antinutrient composition show that processing significantly reduced the levels of oxalate, tannins, phytate, trypsin inhibitor, and hydrogen cyanide contents of $V$. subterranea. While magnesium, potassium, and phosphorus were the most abundant macrominerals in V. subterranea, zinc was the most abundant micromineral. Correlation analysis revealed that the levels of crude protein, ash, moisture, and lipid were negatively affected by phytate, tannins, and oxalate. The results, therefore, suggest that processing significantly lowered the levels of antinutrients in V. subterranea, thereby making it safer for consumption.
\end{abstract}

\section{Introduction}

Vigna subterranea L. (Bambara groundnut) is a pulse with subterranea fruit set and is cultivated by small farm holders over much of semiarid Africa [1]. It is a legume species of African origin [2] and is widespread south of the Sahara [3]. Food legumes have a major role to play in the fight against malnutrition. Legumes serve as a source of protein to a large proportion of the population in poor countries of the world by being the least expensive and easily stored and a transported nonprocessed protein source for rural and urban dwellers [4]. The high carbohydrate $(65 \%)$ and relatively high protein $(18 \%)$ content of $V$. subterranea make it a complete food [5]. It is therefore necessary that their levels of consumption, which are already too low in a number of developing countries, be increased [2].
In Nigeria, $V$. subterranea is processed through various processing techniques like boiling, roasting, and frying. In some parts of the country, the seeds are often crushed into flour, to prepare local dishes like "alele," "alelen ganye," "danwake," "gauda," "kosai," "kunu," "tuwo," and "waina" [6]. In other parts, dried V. subterranea seeds are made into paste and used in the preparation of various fried or steamed products, such as "akara" and "moin-moin" [7], while the fresh immature seeds are eaten raw in some parts of the country. One favorite Nigerian dish made from $V$. subterranea is "okpa," which is a doughy paste that is wrapped and steamed in banana leaves. The different processing techniques utilized often have varied effects on the bioavailability of the nutrients because the degree at which nutrients are lost differs from one processing technique to the other. 
V. subterranea (Bambara groundnut) is a promising commodity which needs more research works to be carried on, both in its raw and processed state. In tropical Africa, very few people in the forest zones are aware of its nutritional benefits. Investigating the effect of processing on the nutritional and the antinutritional components of $V$. subterranea will help to increase the awareness of not only this crop but also its nutritional capabilities. In view of the numerous useful attributes of $V$. subterranea both in terms of its nutritional composition and its ability to resist harsh weather conditions like drought, it is necessary to carry out researches that will help to optimize its benefits especially in Africa where malnutrition occurrences are on the high side.

\section{Materials and Methods}

2.1. Collection and Identification of Vigna subterranea. The Bambara groundnuts (Vigna subterranea) seeds were obtained from local farmers in Fadan Ninzo, Randa, and Gwantu villages, in Sanga Local Government Area of Kaduna South, Kaduna State, North-West Nigeria. The nuts were obtained in September, 2011, identified, and authenticated at the Herbarium unit of the Department of Biological Sciences, Ahmadu Bello University, Zaria, where a voucher number 1321 was deposited. The fresh seeds were divided into two categories: unprocessed (raw) and processed (boiled and roasted).

\subsection{Raw (Unprocessed) Vigna subterranea. Fresh Vigna sub-} terranea seeds were thoroughly cleaned and foreign materials as well as broken and immature seeds were removed. The clean seeds were shade-dried for three (3) consecutive days to a constant weight at room temperature $\left(25-30^{\circ} \mathrm{C}\right)$. The dry seeds were pulverized to fine powder using the laboratory mill (SPI Supplies PA, USA) and stored in an air-tight container at $4-6^{\circ} \mathrm{C}$ until used.

\subsection{Processing Techniques}

2.3.1. Boiling. A set of Bambara groundnut seeds ( $100 \mathrm{~g})$ was boiled in distilled water $\left(100^{\circ} \mathrm{C}\right)$ in a seed to water ratio of $1: 10(\mathrm{w} / \mathrm{v})$ for $3 \mathrm{hrs} 48 \mathrm{~min}$. This is the established time frame known for it to be ready as practiced by the locals. After boiling, the water was drained off and the boiled seeds were mashed into paste using a ceramic mortar and then stored in an air-tight container at $4-6^{\circ} \mathrm{C}$ until used.

2.3.2. Roasting. A second set of the Bambara groundnut seeds $(100 \mathrm{~g})$ placed on a frying pan was roasted for $1 \mathrm{hr}$ using firewood with temperature at about $300^{\circ} \mathrm{C}$ as practiced by the locals. Thereafter, the roasted seeds were pulverized to fine powder using the laboratory mill (SPI supplies PA, USA) and then stored in an air-tight container at $4-6^{\circ} \mathrm{C}$ until used.

2.4. Proximate Analysis. The moisture contents of raw and processed Bambara groundnut seeds were determined after drying at $105^{\circ} \mathrm{C}$ according to the method of InduharaSwamy et al. [8]. Micro-Kjeldahl method was employed in determining the total nitrogen and the crude protein $(\mathrm{N} \times 5.95)$. Crude lipid was extracted with petroleum ether, using a Soxhlet apparatus, and determined based on method outlined in AOAC [9]. Ash contents (gravimetric) were also determined based on methods outlined in AOAC [9]. Total carbohydrate was calculated by difference, summing the percentage values of moisture, crude protein, ash, and crude fat (ether extract) and subtracting the sum from 100 [10]. Gross energy was calculated based on the formula by Eknayake et al. [11]:

$$
\begin{aligned}
& \text { Gross energy }(\mathrm{kJ} \text { per } 100 \mathrm{~g} \text { dry matter }) \\
& \begin{array}{l}
=(\text { crude protein } \times 16.7)+(\text { crude lipid } \times 37.7) \\
\quad+(\text { crude carbohydrates } \times 16.7)
\end{array}
\end{aligned}
$$

Nitrogen free extract (NFE) was calculated by difference as

$$
\mathrm{NFE}=\text { total carbohydrate }- \text { crude fiber. }
$$

2.5. Antinutrient Analysis. Alkaline Titration Method [12] was used for hydrogen cyanide analysis while the method of Reddy et al. [13] was used for phytate analysis. Trypsin inhibitory analysis was done using spectrophotometric method as described by Arntfield et al. [14], while tannin analysis was carried out according to the method of Doss et al. [15] by taking the absorbance at $500 \mathrm{~nm}$ wavelengths. Oxalate determination was carried out based on the method of Leyva et al. [16].

2.6. Mineral Analysis. Potassium, sodium, calcium, magnesium, manganese, phosphorus, copper, zinc, and iron in the processed and raw Bambara groundnut seeds were determined by an X-ray spectrometer (XRS) using a MiniPal 4 Version PW 4030 X-Ray Spectrometer (Perkin Elmer, Inc., USA). The samples were dried at $110^{\circ} \mathrm{C}$ until a constant weight was obtained. The dried samples were weighed and manually grinded using a mortar and a pestle (SPI supplies PA, USA). A binder (PVC dissolved in Toluene) was mixed with the sample to ensure that the sample is sufficiently thick enough to absorb the entire primary beam. This was followed by sieving the sample using a turbulent mixer which was aimed at homogenizing the samples. Pressure of about $7182 \mathrm{mmHg}$ was applied to each sample mass of about $1.5 \mathrm{~g}$ to produce pellets of the samples. The pellets were loaded into the sample chamber of the X-ray spectrometer system.

The spectrometer was operated at a maximum voltage of $30 \mathrm{kV}$. A maximum current of $1 \mathrm{~mA}$ was applied to produce the primary X-rays to excite the pellet. A preset time of 10 minutes (for each of the samples) was employed and an inbuilt $\mathrm{Si}(\mathrm{Li})$ detector was used for counting the secondary $\mathrm{X}$-rays from the sample. The spectrum from the samples was analysed by a computer running a dedicated MiniPal Analytical Software.

2.7. Statistical Analysis. All analyses were carried out in triplicate and results were expressed as mean \pm SD. Analysis of variance (ANOVA) and the Pearson correlation coefficients were carried out using SPSS 17.0. A significant difference of 


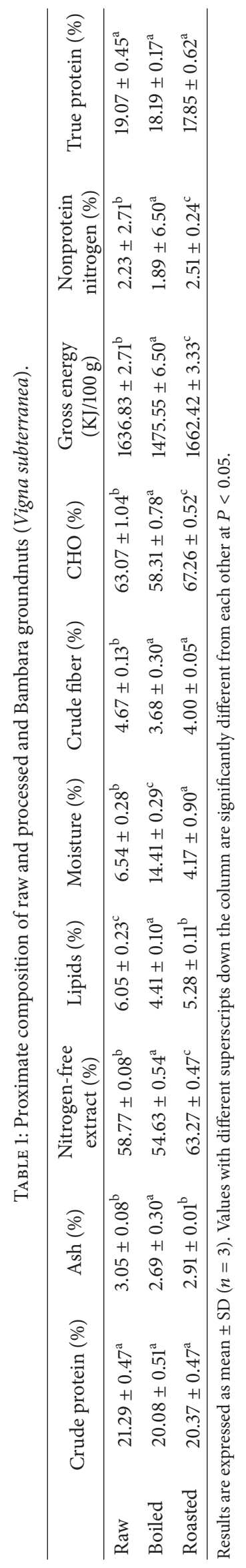


TABLE 2: Antinutrients composition of raw and processed Bambara groundnuts (Vigna subterranea).

\begin{tabular}{lccccc}
\hline & $\begin{array}{c}\text { Oxalate } \\
(\mathrm{mg} / \mathrm{kg})\end{array}$ & $\begin{array}{c}\text { Tannins } \\
(\mathrm{mg} / \mathrm{g})\end{array}$ & $\begin{array}{c}\text { Phytate } \\
(\mathrm{mg} / 100 \mathrm{~g})\end{array}$ & $\begin{array}{c}\text { TIA } \\
(\mathrm{mg} / 100 \mathrm{~g})\end{array}$ & $\begin{array}{c}\text { HCN } \\
(\mathrm{mg} / \mathrm{kg})\end{array}$ \\
\hline Raw & $6.15 \pm 0.07^{\mathrm{c}}$ & $18.61 \pm 0.24^{\mathrm{b}}$ & $319.55 \pm 1.00^{\mathrm{c}}$ & $7.11 \pm 1.41^{\mathrm{c}}$ & $197 \pm 1.41^{\mathrm{c}}$ \\
Boiled & $1.97 \pm 1.00^{\mathrm{a}}$ & $5.33 \pm 0.25^{\mathrm{a}}$ & $113.71 \pm 0.80^{\mathrm{a}}$ & $1.05 \pm 0.41^{\mathrm{a}}$ & $38.73 \pm 0.64^{\mathrm{a}}$ \\
Roasted & $2.96 \pm 0.04^{\mathrm{b}}$ & $5.33 \pm 0.23^{\mathrm{a}}$ & $160.08 \pm 0.96^{\mathrm{b}}$ & $1.89 \pm 0.96^{\mathrm{b}}$ & $42.94 \pm 0.49^{\mathrm{b}}$ \\
Permissible limits & $5 \mathrm{mg} / \mathrm{kg}$ & $20 \mathrm{mg} / \mathrm{g}$ & $250 \mathrm{mg}$ & $0.7-3.0 \mathrm{mg} / 100 \mathrm{~g}$ & $50 \mathrm{mg} / \mathrm{kg}$ \\
\hline
\end{tabular}

Results are expressed as mean $\pm \mathrm{SD}$. Values with different superscripts down the column are significantly different from each other at $P<0.05$.

TABLE 3: Mineral composition of raw and processed Bambara groundnuts (Vigna subterranea).

\begin{tabular}{|c|c|c|c|c|}
\hline Element & $\begin{array}{c}\text { Boiled } \\
(\mathrm{mg} / 100 \mathrm{~g})\end{array}$ & $\begin{array}{l}\text { Roasted } \\
(\mathrm{mg} / 100 \mathrm{~g})\end{array}$ & $\begin{array}{c}\text { Raw } \\
(\mathrm{mg} / 100 \mathrm{~g})\end{array}$ & $\begin{array}{l}{ }^{\mathrm{a}} \text { Recommended dietary } \\
\text { allowance (RDA) in mg/day }\end{array}$ \\
\hline $\mathrm{Ca}$ & $12.09 \pm 1.54^{\mathrm{a}}$ & $19.63 \pm 1.94^{\mathrm{b}}$ & $15.06 \pm 1.32^{\mathrm{ab}}$ & $210-800^{*}, 800^{* *}, 1200^{* * *}$ \\
\hline K & $186.17 \pm 1.17^{\mathrm{a}}$ & $195.54 \pm 3.48^{\mathrm{b}}$ & $187.07 \pm 0.09^{\mathrm{a}}$ & $400-3000^{*}, 4700^{* *, * * *}$ \\
\hline $\mathrm{Cu}$ & $3.05 \pm 0.07^{\mathrm{ab}}$ & $2.05 \pm 0.64^{\mathrm{a}}$ & $4.61 \pm 0.84^{\mathrm{b}}$ & $0.2-0.44^{*}, 0.7-0.89^{* *}, 0.9^{* * *}$ \\
\hline $\mathrm{Fe}$ & $1.58 \pm 0.30^{\mathrm{a}}$ & $1.60 \pm 0.32^{\mathrm{a}}$ & $1.69 \pm 0.42^{\mathrm{a}}$ & $0.27-11^{*}, 8-15^{* *}, 10^{* * *}$ \\
\hline $\mathrm{Mn}$ & $3.01 \pm 0.61^{\mathrm{a}}$ & $4.08 \pm 0.16^{\mathrm{ab}}$ & $5.65 \pm 0.78^{\mathrm{b}}$ & $0.003-1.5^{*}, 1.6-2.2^{* *}, 1.8-2.3^{* * *}$ \\
\hline $\mathrm{Zn}$ & $20.98 \pm 1.07^{\mathrm{b}}$ & $10.27 \pm 1.33^{\mathrm{a}}$ & $20.20 \pm 0.92^{\mathrm{b}}$ & $2-5^{*}, 11^{* *}, 15^{* * *}$ \\
\hline $\mathrm{Mg}$ & $65.30 \pm 3.25^{\mathrm{a}}$ & $67.67 \pm 2.36^{\mathrm{a}}$ & $63.51 \pm 2.13^{\mathrm{a}}$ & $30-130^{*}, 240-360^{* *}, 320-340^{* * *}$ \\
\hline $\mathrm{P}$ & $100.67 \pm 3.30^{\mathrm{b}}$ & $132.25 \pm 6.01^{c}$ & $76.98 \pm 4.28^{\mathrm{a}}$ & $100-500^{*}, 1250^{* *}, 700^{* * *}$ \\
\hline $\mathrm{Na}$ & $23.27 \pm 2.45^{\mathrm{a}}$ & $25.23 \pm 1.09^{\mathrm{a}}$ & $21.03 \pm 2.79^{\mathrm{a}}$ & $120^{*}, 1500^{* * * * * *}$ \\
\hline
\end{tabular}

Results are expressed as mean \pm SD. Values with different superscripts across the row are significantly different from each other at $P<0.05$.

${ }^{a}$ Culled from the United States Department of Agriculture (USDA) and may be accessed via http://www.nap.edu/.

${ }^{*}$ Infants; ${ }^{* *}$ children; ${ }^{* * *}$ adults.

$P<0.05$ was ascribed for ANOVA and $P<0.05$ and 0.01 for Pearson correlation. The differences in means were compared using Duncan's new multiple range test.

\section{Results and Discussion}

3.1. Proximate Composition. The effect of processing (boiling and roasting) on the proximate composition of Bambara groundnut is presented in Table 1. It shows that boiling and roasting had no significant $(P<0.05)$ effect on the values of crude and true proteins. Nitrogen-free extract and nonprotein nitrogen were, however, significantly $(P<0.05)$ reduced by boiling but significantly improved by roasting. Similarly, carbohydrate and gross energy content were significantly $(P<0.05)$ reduced by boiling but significantly improved by roasting. Lipid and crude fiber contents were significantly reduced by both boiling and roasting, with boiling causing a more significant reduction in lipid content than roasting. Ash content was not significantly $(P<0.05)$ affected by roasting but was significantly reduced by boiling while moisture content on the other hand was significantly improved by boiling but significantly reduced by roasting.

The value of proximate composition of raw Bambara Groundnut agrees with the finding of Brough et al. [17]. The slightly lower value of crude protein in boiled Bambara groundnut as compared to the raw and roasted form recorded in this research might be as a result of leaching of soluble proteins into cooking water. A similar observation was made by Adeparusi [18] when boiling Lima beans (Phaseolus lunatus L.). Bambara groundnut based on the result of this research makes a complete food, as it contains sufficient quantities of protein, carbohydrate, and fat. A similar observation has been reported by Oluyemi et al. [19] and Oliveira [20].

3.2. Antinutrients. The levels of oxalate, phytate, hydrogen cyanide, and trypsin inhibitors activities (TIA) (which were above the permissible limits in the raw Bambara groundnut) were hugely reduced significantly $(P<0.05)$ to permissible levels by both boiling and roasting (Table 2) with boiling causing more significant reduction than roasting. Both processing methods, however, had the same significant $(P<$ 0.05 ) reducing effect on the level of tannin.

The reduction in the trypsin inhibitors activities (TIA) of Bambara groundnut by the two processing techniques employed in this study agrees with the work of Walker and Kochhar [21] who recommended moist heat treatment as a means of reducing the amount of TIA in legumes below critical level. The reduction in phytate contents is in agreement with the work of Ene-Obong and Obizoba [22] who reported reduction of phytic acids in boiled Bambara groundnut by up to $74 \%$. Phytates are known to reduce bioavailability of minerals; impair protein digestibility caused by formation of phytic-protein complexes; and hinder absorption of nutrients due to damage to the pyloric caeca region of the intestine [23]. Tannin contents of Bambara groundnuts also reduced by the processing methods employed agrees with the report of Adeparusi [18] and Nyachoti et al. [24]. Antinutritional effects of tannins include interference with the digestive processes either by binding enzymes or by binding to food components like proteins or minerals [25]. Tannins also have the ability to complex with vitamin $B_{12}[22,26]$. 


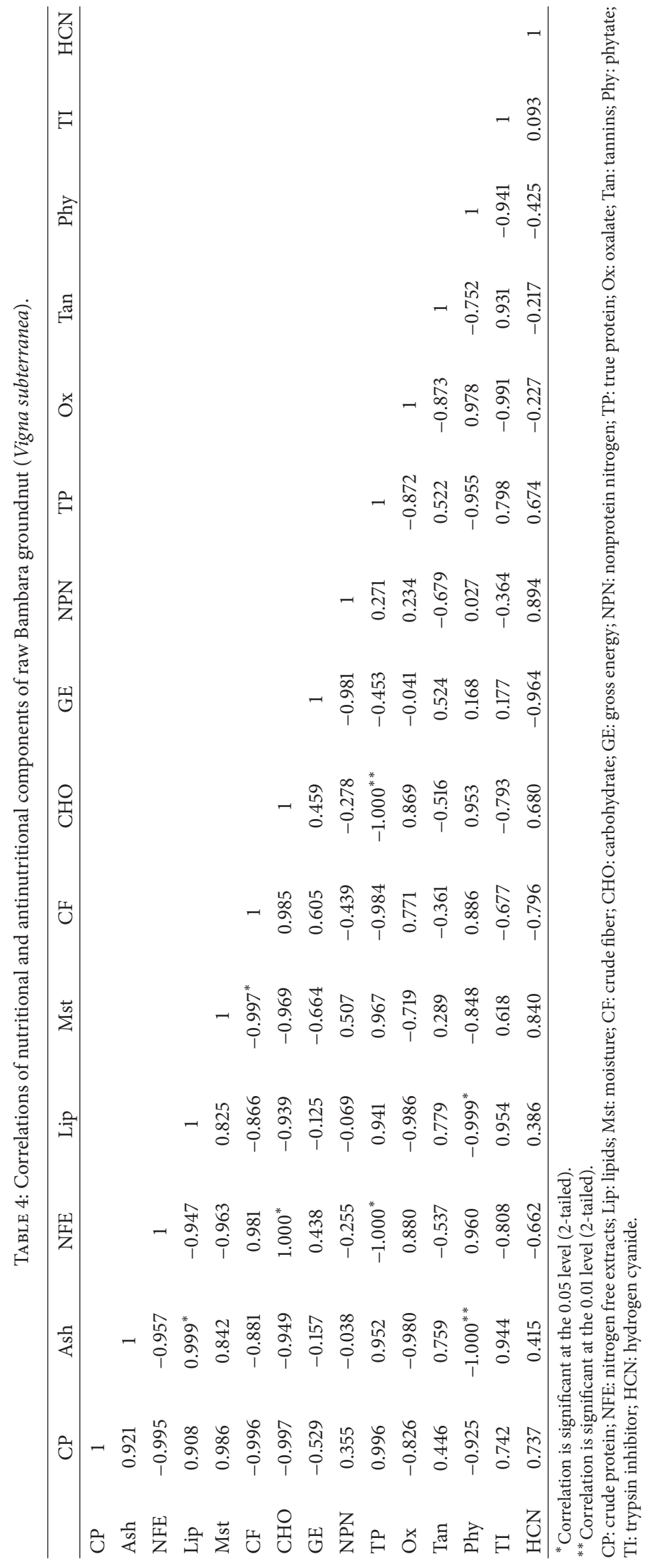




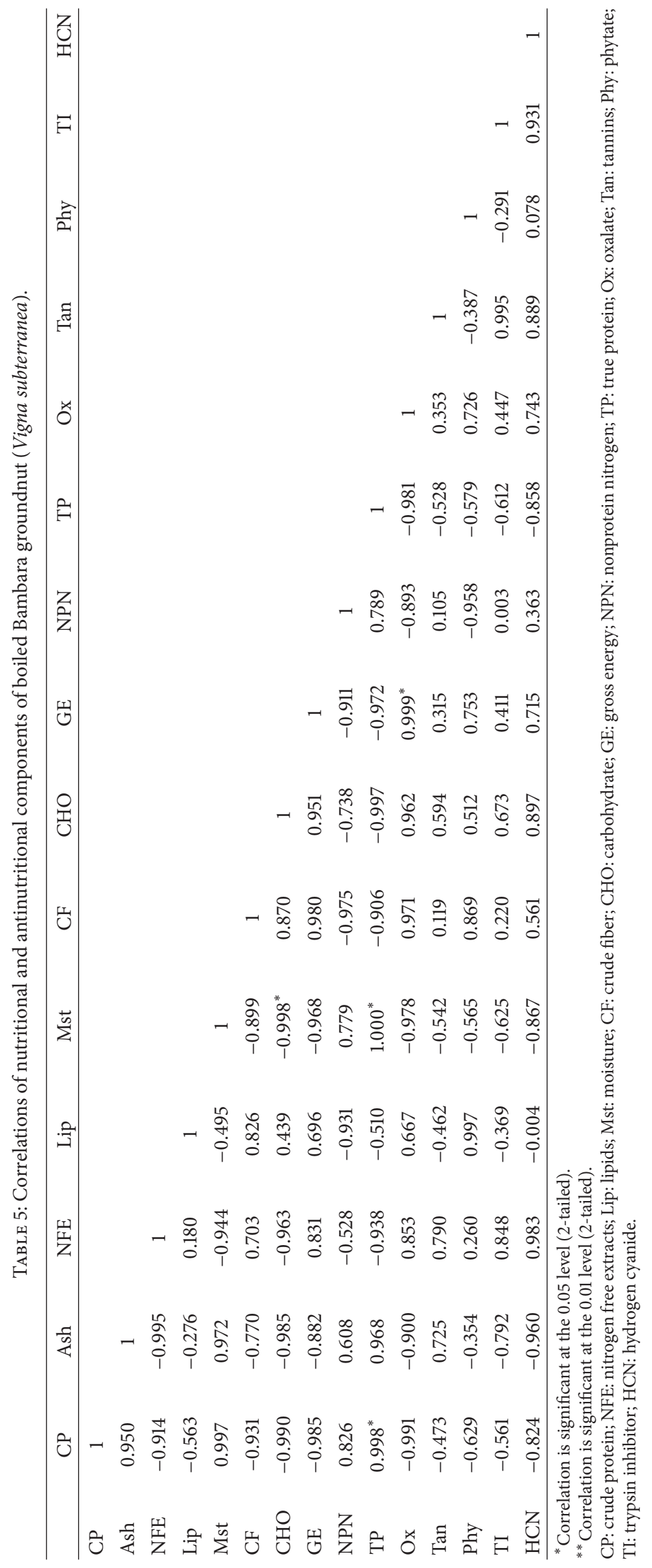




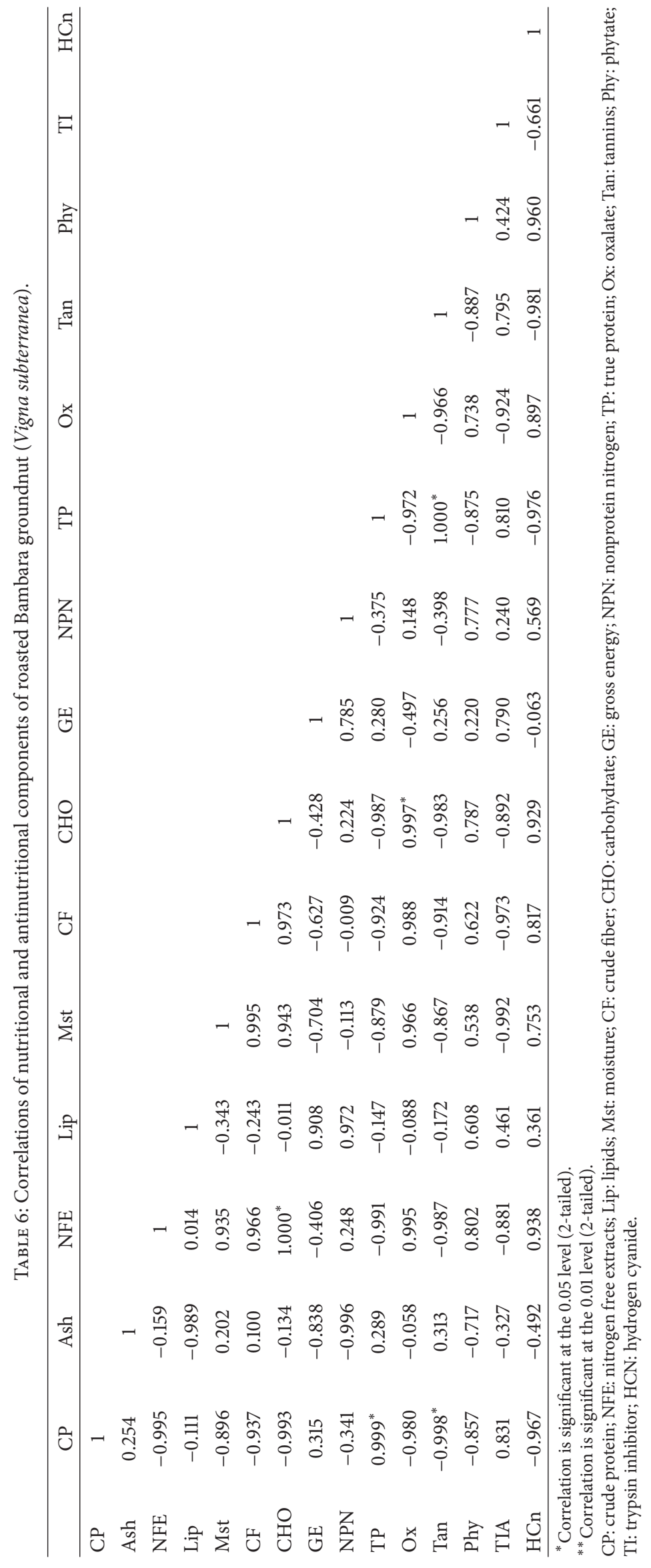


3.3. Minerals. From the result presented in Table 3, boiling significantly $(P<0.05)$ reduced the percentage levels of calcium, cupper, and manganese and insignificantly reduced the percentage levels of potassium and iron. It, however, significantly $(P<0.05)$ improved the percentage levels of zinc, magnesium, and sodium but caused an insignificant $(P>0.05)$ improvement in the percentage level of phosphorus. Roasting, on the other hand, significantly $(P<0.05)$ improved the percentage levels of calcium, potassium, and phosphorus and insignificantly $(P>0.05)$ improved the percentage levels of sodium and magnesium. It, however, had a significant $(P<0.05)$ reducing effect on the percentage levels of cupper, manganese, and zinc and an insignificant $(P>0.05)$ reducing effect on the percentage levels of iron.

The percentage values of macrominerals recorded in this study agrees with earlier works by Agren and Gibson [27]. High content of macrominerals, especially zinc, $20.98 \%$, in the boiled Bambara groundnut and magnesium, $65.30 \%$ and $67.67 \%$, in boiled and roasted Bambara groundnut, respectively, is a plus to its nutritional quality.

3.4. Correlation Analyses. Table 4 showed the correlation matrix between nutritional and antinutritional components of raw Bambara groundnut in which there was a perfect positive relationship $\left(r=1.000^{*}\right)$ significant at 0.05 level (2tailed) between carbohydrate and nitrogen-free extract and a near perfect positive relationship $\left(r=0.999^{*}\right)$ significant at 0.05 level (2-tailed) between ash and lipid contents of the raw Bambara groundnut. A perfect negative relationship $\left(r=-1.000^{*}\right)$ significant at 0.05 level (2-tailed) was exhibited between true protein and nitrogen-free extract. Similarly, a perfect negative relationship was exhibited between phytate and ash content and also between true protein and carbohydrate content $\left(r=-1.000^{* *}\right)$, although their significance was at 0.01 level (2-tailed). The relationship between phytate and lipid and that between crude fiber and moisture content were a near perfect negative relationship $(r=-0.999$ and $r=-0.997$, resp.) significant at 0.05 level (2-tailed).

Correlations of nutritional and antinutritional components of boiled Bambara groundnut shown in Table 5 indicate a perfect positive relationship $\left(r=1.000^{*}\right)$ significant at 0.05 level (2-tailed) between true protein and moisture content and a near perfect positive relationship between crude protein and true protein $\left(r=0.998^{*}\right)$ and also between oxalate and gross energy both significant at 0.05 level (2-tailed). A near perfect negative relationship was observed between moisture and carbohydrate content $(r=-0.999)$ significant at 0.05 level (2-tailed).

Table 6 shows the correlations of nutritional and antinutritional components of roasted Bambara groundnut and indicates a perfect positive relationship $\left(r=1.000^{*}\right)$ significant at 0.05 level (2-tailed) between carbohydrate and nitrogen-free extract and also between tannins and true protein. A near perfect positive relationship $\left(r=0.999^{*}\right)$ significant at 0.05 level (2-tailed) was observed between crude protein and true protein. A similar relationship was also recorded between oxalate and carbohydrate $\left(r=0.997^{*}\right)$ significant at 0.05 level (2-tailed).
The correlation analyses of raw Bambara groundnut indicate that phytate will negatively affect the mineral level (ash) of unprocessed Bambara groundnut and make some vital nutrients unavailable. However, this negative effect was reduced by both processing techniques. These findings are in agreement with earlier work by Ndidi et al. [28] which suggest that some of the antinutrients in Sphenostylis stenocarpa negatively affect the availability of the nutrients and minerals; however, the effects were reduced by processing.

\section{Conclusion}

Boiling and roasting reduced the antinutritional properties of Bambara groundnuts below the permissible limits. This suggests possible enhancement in quality and safety of the nuts with increasing boiling or roasting time. Although longer time was employed to process the nuts by boiling, it was more efficient in reducing the antinutrients content of Bambara groundnuts, implying that the antinutrients are more susceptible to moist heat than dry heat. The significant reduction of antinutrients during processing suggests that the nutritional components of Bambara groundnuts will be more bioavailable. This research work suggests that Bambara groundnut has tremendous potential in alleviating protein energy malnutrition in Africa, since it is nutritionally rich in carbohydrate and protein.

\section{Conflict of Interests}

The authors declare that there is no conflict of interests regarding the publication of this paper.

\section{References}

[1] A. R. Linnemann and S. Azam-Ali, "Bambara groundnut (Vigna subterranea (L.) Verdc.)," in Underutilized Crops Series 2. Vegetables and Pulses, J. T. Williams, Ed., pp. 13-58, Chapman \& Hall, London, UK, 1993.

[2] M. Borget, Food Legumes, The Tropical Agriculturalist, CTA Macmillan, 1992.

[3] V. K. Ocran, L. L. Delimini, R. A. Asuboah, and E. A. Asiedu, Seed Management Manual for Ghana, MOFA, Accra, Ghana, 1998.

[4] K. O. Rachie and P. Silvestre, "Grain legumes," in Food Crops of the Lowland Tropics, C. L. Leakey and J. B. Wills, Eds., pp. 41-74, Oxford University Press, London, UK, 1977.

[5] E. V. Doku and S. K. Karikari, "Flowering and pod production of bambara groundnut (Voandzeia subterranea Thou.) in Ghana," Ghana Journal of Agricultural Science, vol. 3, no. 1, pp. 17-26, 1970.

[6] A. R. Linnemann, "Cultivation of bambara groundnut in Northern Nigeria," Tropical Crops and Communications, vol. 15, pp. 114, 1988.

[7] A. O. Oguntunde, "Development of new food products from readily available raw materials," in Proceedings of the Nigerian Institute of Food Science and Technology Training Workshop, Ibadan, Nigeria, 1985.

[8] Y. M. InduharaSwamy, S. Z. Ali, and K. R. Bhattarcharya, "Hydration of raw and parboiled rice and paddy at room 
temperature," Journal of Food Science and Technology, vol. 8, no. 1, pp. 20-22, 1971.

[9] AOAC, Official Method of Analysis, Association of Official Analytical Chemists, Washington, DC, USA, 17th edition, 2000.

[10] P. McDonald, R. A. Edwards, and J. F. D. Green-halgh, Animal Nutrition, T \& A Constable Ltd, Edinburgh, Scotland, 1973.

[11] S. Eknayake, E. R. Jansz, and B. M. Nair, "Proximate composition, mineral and amino acid content of mature Canavalia gladiata seeds," Food Chemistry, vol. 66, no. 1, pp. 115-119, 1999.

[12] AOAC, Official Methods of Analysis, K. Helrich, Ed., Association of Official Analytical Chemists (AOAC), Arlingron, Va, USA, 15th edition, 1990.

[13] N. R. Reddy, S. K. Sathe, and D. K. Salunkhe, "Phytates in legumes and cereals," Advances in Food Research, vol. 28, pp. 192, 1982.

[14] S. D. Arntfield, M. A. H. Ismond, and E. D. Murray, "The fate of anti-nutritional factors during the preparation of faba bean protein isolates using a micellization technique," Canadian Institute of Food Science and Technology Journal, vol. 18, no. 2, pp.137-143, 1985.

[15] A. Doss, M. Pugalenthi, V. G. Vadivel, G. Subhashini, and R. Anitha Subash, "Effects of processing technique on the nutritional composition and antinutrients content of under-utilized food legume Canavalia ensiformis L.DC," International Food Research Journal, vol. 18, no. 3, pp. 965-970, 2011.

[16] J. A. M. Leyva, M. P. H. Artiga, M. M. A. Mendez, and J. J. Q. Perez, "Atomic absorption and UV-VIS absorption spectrophotometric determination of oxalate in urine by ligand exchange extraction," Clinica Chimica Acta, vol. 195, no. 1-2, pp. 47-56, 1990.

[17] S. H. Brough, S. N. Azam-Ali, and A. J. Taylor, "The potential of bambara groundnut (Vigna subterranea) in vegetable milk production and basic protein functionality systems," Food Chemistry, vol. 47, no. 3, pp. 277-283, 1993.

[18] E. O. Adeparusi, "Effect of processing on the nutrients and anti-nutrients of Lima zean (Phaseolus lunatus L.) flour," Nahrung/Food, vol. 45, no. 2, pp. 94-96, 2001.

[19] J. A. Oluyemi, B. L. Fetuga, and H. N. L. Endeley, "The metabolizable energy value of some feed ingredients for young chicks," Poultry Science, vol. 55, no. 2, pp. 611-618, 1976.

[20] J. S. Oliveira, "Grain legumes of Mozambique," Tropical Grain Legume Bulletin, vol. 3, pp. 13-15, 1976.

[21] A. F. Walker and N. Kochhar, "Effect of cooking including domestic cooking on nutritional quality of legumes," Proceedings of the Nutrition Society, vol. 41, pp. 41-51, 1982.

[22] H. N. Ene-Obong and I. C. Obizoba, "Effect of domestic processing on the cooking time, nutrients, antinutrients and in vitro Protein digestibility of the African yambean (Sphenostylis stenocarpa)," Plant Foods for Human Nutrition, vol. 49, no. 1, pp. 43$52,1996$.

[23] G. Francis, H. P. S. Makkar, and K. Becker, "Antinutritional factors present in plant-derived alternate fish feed ingredients and their effects in fish," Aquaculture, vol. 199, no. 3-4, pp. 197227, 2001.

[24] C. M. Nyachoti, J. L. Atkinson, and S. Leeson, "Sorghum tannins: a review," World's Poultry Science Journal, vol. 53, no. 1, pp. 15-21, 1997.

[25] R. G. Elkin, J. C. Rogler, and T. W. Sullivan, "Comparative effects of dietary tannins in ducks, chicks, and rats.," Poultry science, vol. 69 , no. 10, pp. 1685-1693, 1990.
[26] I. E. Liener, Toxic Constituents of Plant Foodstuffs, Academic Press, New York, NY, USA, 1980.

[27] G. Agren and R. Gibson, Food Composition Table for Use in Ethiopia, Children's Nutrition Unit, Addis Ababa, Ethiopia, 2008.

[28] U. S. Ndidi, C. U. Ndidi, A. Olagunju, A. Muhammad, F. G. Billy, and O. Okpe, "Proximate, Antinutrients and mineral composition of raw and processed (boiled and roasted) Sphenostylis stenocarpa seeds from Southern Kaduna, Northwest, Nigeria," ISRN Nutrition, vol. 2014, Article ID 280837, 9 pages, 2014. 

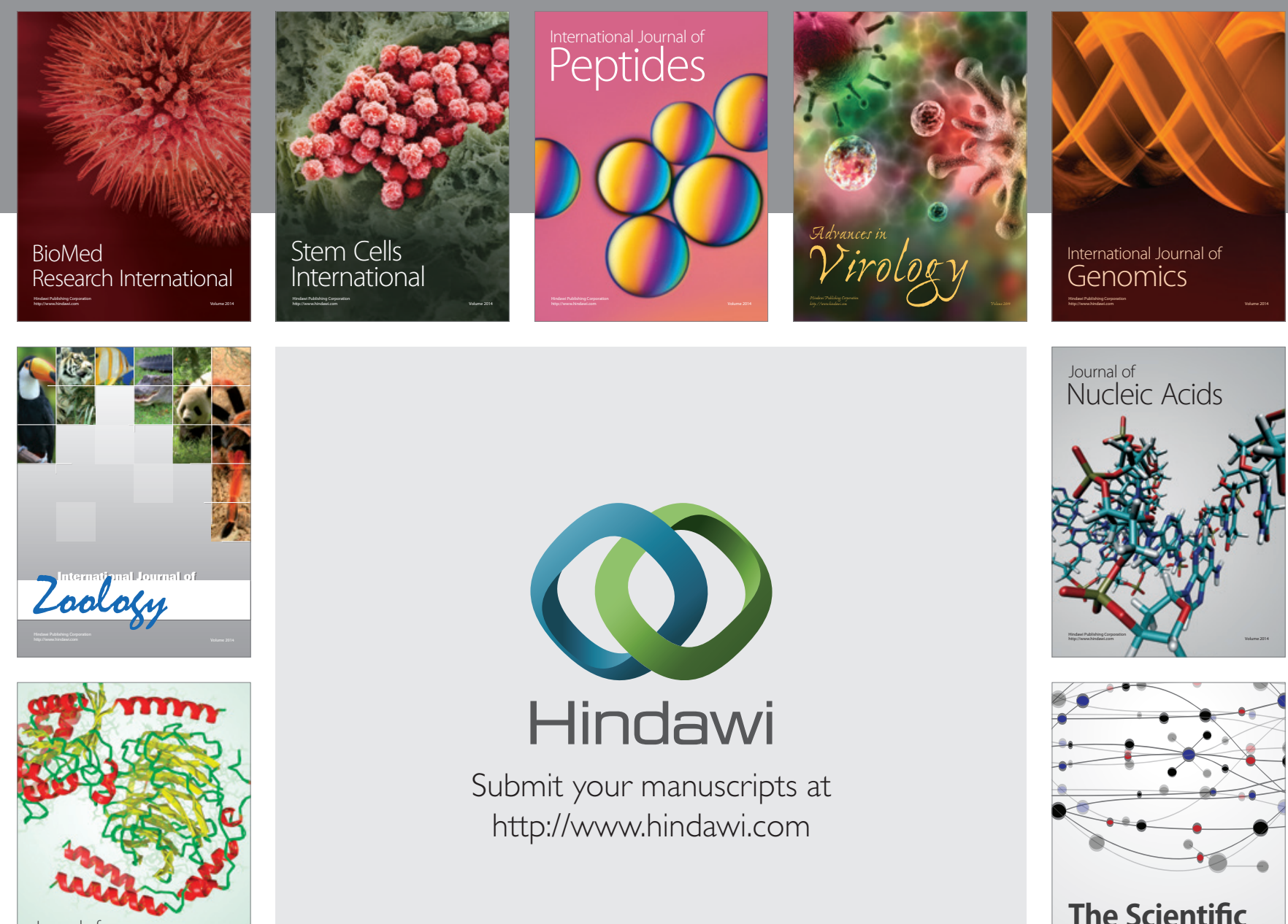

Submit your manuscripts at

http://www.hindawi.com

Journal of
Signal Transduction
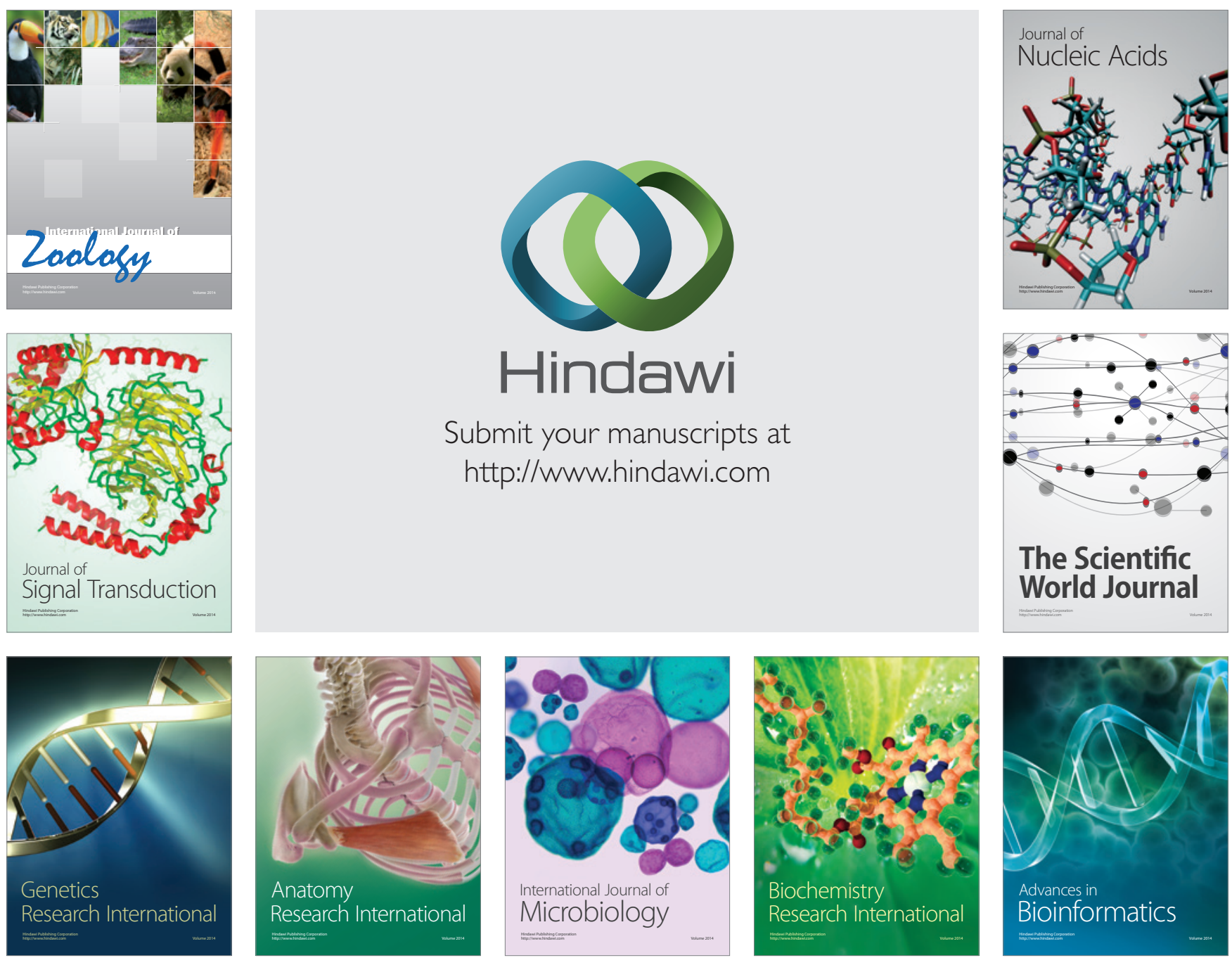

The Scientific World Journal
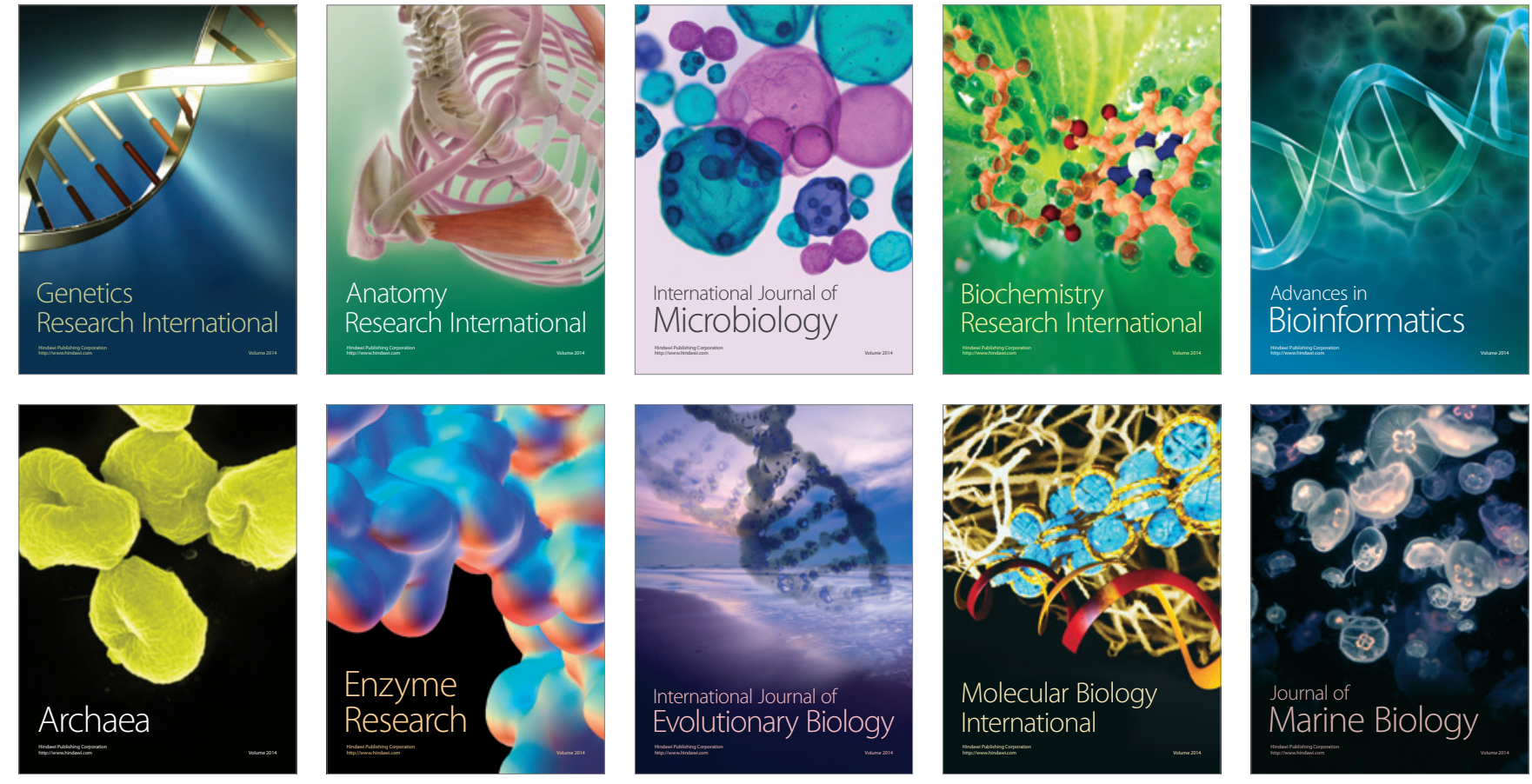